\title{
Misrecognizing Muslim consciousness in Europe
} Nasar Meer

Ethnicities 2012 12: 178 originally published online 10 January 2012 DOI: $10.1177 / 1468796811431295$

The online version of this article can be found at:

http://etn.sagepub.com/content/12/2/178

\author{
Published by: \\ (9)SAGE \\ http://www.sagepublications.com
}

Additional services and information for Ethnicities can be found at:

Email Alerts: http://etn.sagepub.com/cgi/alerts

Subscriptions: http://etn.sagepub.com/subscriptions

Reprints: http://www.sagepub.com/journalsReprints.nav

Permissions: http://www.sagepub.com/journalsPermissions.nav

Citations: http://etn.sagepub.com/content/12/2/178.refs.html

\author{
>> Version of Record - Mar 28, 2012 \\ OnlineFirst Version of Record - Jan 10, 2012 \\ What is This?
}


Misrecognizing Muslim consciousness in Europe

\author{
Nasar Meer
}

Northumbria University, UK
12(2) 178-196

(C) The Author(s) 2012

Reprints and permissions: sagepub.co.uk/journalsPermissions.nav DOI: I0.1 I77/|4687968| |43।295 etn.sagepub.com

\begin{abstract}
It is widely accepted that the category of 'Muslim' in Europe is patterned by a variety of subjective and objective features. Despite internal difference, some argue that there emerges something overarching that furnishes Muslims in Europe with a collective sense of self, evidenced by empirically observable Muslim identities at local, national and supra-national levels. Amongst those who share this view at least three prevailing interpretations have emerged. The first is theologically grounded but socially iterative. It maintains that Europe's Muslims are redefining Islam in the context of their identities as European Muslims and that the result is a 'Euro-Islam', illustrated by how Muslims view Europe as their home while being guided by a renewed Islamic doctrine. A second interpretation of a 'Muslim subject' in Europe can be described as the 'Eurabia' trajectory. This predicts the numerical and cultural domination of Europe by Muslims and Islam. The third is more formally sociological and employs a methodology of political claims-making to report that Muslims in Europe are exceptional in not following pathdependent institutional opportunity structures of minority integration. This article argues that these formulations are open to the charge that each places the burden of adaptation upon Muslim minorities. As such each displays a normative 'position' or Weltanschauung that misrecognizes dynamic components of what may be termed 'Muslim-consciousness'. The article maintains that the components of Muslim consciousness contain compelling evidence that Muslims in Europe are meeting standards of reasonableness in their political claims-making, often from contexts in which they face profound social and political adversity.
\end{abstract}

\title{
Keywords
}

citizenship, Europe, identity, Islam, misrecognition, Muslims

\section{Corresponding author:}

Nasar Meer, Department of Social Sciences, Northumbria University, Lipman Building, Newcastle upon Tyne, NEI 8ST, UK

Email: nasar.meer@northumbria.ac.uk 


\section{Introduction}

There is a moderately well-known Greek myth, often traced to the Iliad, which is deemed to contain one of the earliest invocations of the idea of Europe. It is an account that tells of how Zeus became enthralled by the Phoenician princess Europa, to the extent that he abducted and removed her to Crete where she became queen. This queen and her journey are sometimes appropriated symbolically as 'a true illustration of what we collectively recognise as the origins of European culture' (Holm, 1999: xi). The myth more broadly serves, first, as a literary reminder of how, in contrast to Europe's contemporary northern centres of politics and economics, the very idea of Europe has its provenance on the shores of the Mediterranean (Braudel, 1995). Second, it is an illustration of how Europe is not simply a political entity in the form of the European Union, but is also a dynamic matrix of cultural inheritance whose porous boundaries have been shaped both inside and beyond its present frontiers.

This is, at least, one view. Some competing but no less reasonable characterizations of the idea of Europe employ a more binary approach in maintaining that 'the birth of Europe took place in an age of Carolingians in a world-historical interaction with the still young but expanding Islamic civilisation' (Tibi, 2008: 162). The fuller implication is that from this point onwards 'the foundation of a European identity was basically Christian', something that was 'reshaped at the eve of the Renaissance', and later still became 'more secular' in the development of its 'civilisational identity' (Tibi, 2008: 162). While this broad historical view of the provenance of 'a European identity' may be one amongst many debated by historians, it is the contemporary implications of Tibi's account that set the scene for the focus of our discussion. These emerge in his summation that while 'the world of Islam was located beyond the southern and eastern Mediterranean boundaries... [c]ontemporary Islamic migration to Europe has changed this feature: no Mediterranean boundary exists anymore, because Islam is now within Europe itself' (Tibi, 2008: 162).

Tibi's statement offers a useful contextual account, for while it is broadly accepted that the categories of 'Islam' and 'Muslim' in Europe are today patterned by a variety of subjective and objective sociological and political differences, a number of intellectual positions agree that despite internal variation there is something overarching that furnishes Muslims in Europe with a collective sense of self. This is something, it is maintained, which is evidenced by empirically observable Muslim identity-related challenges to established social and political configurations at local, national and supranational levels.

While the notion of a 'Muslim subject' in Europe is by no means uncontested, inviting long-established charges of essentialism and reification, this article will focus on the tensions within - rather than a refutation of - at least three predominant interpretations. The first of these is theologically grounded but socially iterative. It maintains that Europe's Muslims are redefining Islam in the context of 
their identities as European Muslims, and that the consequence is a 'Euro-Islam': something illustrated by how Muslims view Europe as their home while being guided by a revised Islamic doctrine. Two competing exponents of this view are Tariq Ramadan and the aforementioned Bassam Tibi. A second interpretation of a 'Muslim subject' in Europe can be described as the 'Eurabia' trajectory. This predicts the numerical and cultural domination of Europe by Muslims and Islam. Its chief exponents include (but are no means limited to) Chris Caldwell and Mark Steyn, who, though differing in several respects, share the view that at a time of alleged demographic, political and cultural weakness in Europe, 'pre-modern Islam will beat post-modern Christianity' (Steyn, 2006b). A third interpretation is more formally sociological and employs a methodology of political claims-making. It reports that Muslims in Europe are 'exceptional' in not following path-dependent institutional opportunity structures of minority integration. That is to say that, taken as an aggregate, accommodating Muslims will be more difficult because Islam is more publicly confessional than other faiths, refuses to be privatized, and instead advances into the public realm of politics in collective and exceptional ways. Different exponents of this view can include Christian Joppke, and Ruud Koopmans and Paul Statham.

In what follows, this article tentatively argues that each of these formulations places the burden of adaptation upon Muslim minorities. As such each displays a normative 'position' or Weltanschauung that misrecognizes dynamic components of what may be termed 'Muslim-consciousness' (Meer, 2010). Taking up the opportunity presented by this special issue to consider seriously the issue of religion in general, and concomitantly by drawing upon notions of recognition and misrecognition elaborated in our introduction, the article maintains that Muslim consciousness comprises components that contain compelling evidence that Muslims in Europe are meeting standards of reasonableness in their identity articulations, often from contexts in which they face profound social and political adversity.

To elaborate this argument, the article is set out as follows. The next section tackles some issues of definition by considering a 'religious' characterization of Muslim identity. Following this, the article briefly outlines what is taken to be at least three salient interpretations of the emergence of Muslim presence in Europe through an account of the writers understood to be their leading exponents. What is offered may be open to the charge of simplification but hopefully not misrepresentation. This is followed by what is deemed a more reasonable 'sociological' characterization of Muslim identity that is able to recognize the dynamic components of Muslim-consciousness in contemporary Europe.

\section{'Religious' characterizations of Muslim-consciousness}

It would be relatively uncontroversial to note that writers use the descriptive terms 'Islam' and 'Muslim' in ways that assume they have been operationalized, so that we intuitively understand what they mean and represent. Like many other concepts, however, on closer inspection it is clear they host a variety of meanings. 
To begin to unpack these terms, we can ask some obvious questions about what Islam denotes and what being Muslim entails. Oliver Roy's (2004) account of Globalised Islam begins in this way:

Who do we call Muslim? A mosque-goer, the child of Muslim parents, somebody with a specific ethnic background (an Arab, a Pakistani), or one who shares with another a specific culture? What is Islam? A set of beliefs based on a revealed book, a culture linked to historical civilisation? A set of norms and values that can be adapted to different cultures? An inherited legacy based on a common origin? (Roy, 2004: 21)

A robust account of Islamic history, civilization and comparative ethnic relations is beyond the scope of this article; indeed, definitive and categorical definitions are neither sought nor - it will be argued -reflect how Muslims view themselves and Islam. Therefore a more modest and relevant exposition could begin by exploring what we mean when we talk about Islam. Is it solely a religion whose first prophet was Adam and last prophet was Mohammed? Is it a state of peace achieved through surrender to God, or is it a political and cultural movement? What is meant by the phrase 'Islam is a way of life'? And can we distinguish Islam as a name of a religion, from the adjective 'Islamic', and the noun 'Muslim'? To answer these questions abstractly, Ahmet Karamustafa (2004: 108) encourages us to approach our conception of Islam by viewing it as a sprawling civilizational project that is 'under continuous construction and renovation in accordance with multiple blueprints... all generated from a nucleus of key ideas and practices ultimately linked to the historical legacy of the Prophet Mohammed'. With this enormous stress upon heterogeneity, how, in tangible terms, can we derive an understanding of Muslim identity? Karamustafa's answer is to focus on how this nucleus of ideas represents:

a set of beliefs (a version each of monotheism, prophecy, genesis, and eschatology) that underwrite a set of values (dignity of human life, individual and collective rights and duties, the necessity of ethical human conduct - in short, a comprehensive moral program), in turn reflected in a set of concrete human acts (ranging from the necessity of greeting others to acts of humility like prayer). (2004: 108)

On a day-to-day basis we can find these ideas articulated in Islamic rituals and the practice of the pillars of Islam - Iman (articles of faith), salat (daily prayer), zakat (charity), sawm (fasting during Ramadan) and hajj (pilgrimage). In this way Islam comprising the beliefs, values, rights and duties emphasized by Karamustafa - is lived rather than simply practised. As Dilwar Hussain (2005: 39) notes 'the congregational prayer is often held as an example of a community in harmony with believers standing in rows and functioning with one body. Fasting and charity sensitize the believers to those who lead less fortunate lives and make the war against global poverty a vivid reality. The pilgrimage symbolizes equality and the breaking of barriers between nations, classes and tongues.' 
In these religious characterizations of Muslim consciousness, participation is necessitated in some or all of the above practices if one is to consider oneself a Muslim, and it is precisely what informs our first interpretation of a 'Muslim subject' in Europe. This is a view that is theologically grounded but socially iterative. It maintains that Europe's Muslims are redefining Islam in the context of their identities as European Muslims and that the outcome is a 'Euro-Islam' illustrated by how Muslims can view Europe as their home while being guided by a renewed Islamic doctrine.

\section{Euro-Islam - the promise of theology}

Two competing exponents of this view are Tariq Ramadan and the Bassam Tibi. The origins of the term Euro-Islam may be traced to a variety of sources but is forthrightly claimed by Tibi, ${ }^{1}$ though it may also be sourced to Al Sayyad and Castells (2002) and Ramadan (1999). Its precise provenance, however, is less at issue than what it denotes. For Ramadan (2004: 4), it describes a process already underway in which 'more and more young people and intellectuals are actively looking for a way to live in harmony with their faith, participating in the societies that are their societies, whether they like it or not'. Ramadan perceives this to be the cultivation of a 'Muslim personality', one that is 'faithful to the principles of Islam, dressed in European and American cultures, and definitively rooted in Western societies.' (2004: 4) He continues:

While our fellow-citizens speak of this 'integration' of Muslims 'among us', the question for the Muslims presents itself differently: their universal principles teach them that wherever the law respects their integrity and their freedom of worship, they are at home and must consider the attainments of these societies as their own and must involve themselves, with their fellow-citizens, in making it good and better. (2004: 5)

Ramadan is thus prioritizing a scriptural inheritance that needs to be reconciled with current and future lived practice, in a manner that reflects 'a testimony based on faith, spirituality, values, a sense of where boundaries lie', something that 'reverses the perception based on the old concepts' (2004: 73). A key theological obstacle that Ramadan therefore seeks to overcome is that of the distinction between Dar Al-Islam (abode of Islam) and Dar Al-Harb (abode of war), a concern that is illustrative of his wider thesis.

Muslims can recognize the 'abode of Islam', maintains Ramadan, by the fact that they are able to practise their religion freely and live their lives in a manner that is consistent with Islamic prescription. For Ramadan, this is a question of freedom of worship that is quite different from a question of the wider institutionalization of Islam and/or non-practice of Islam in any given society. He elaborates this at length to contrast it with its anti-thesis, 'the abode of war', in which the legal system as well as the government are anti-Islamic. The important point for Ramadan is to recognize that this distinction does not turn on the distinction 
between Muslim and non-Muslim contexts because it may well be the case that a majority-Muslim society, where the legal and political system prevents Muslims from living in accordance with their Islamic prescription, constitutes Dar Al-Harb.

This reasoning leads to an interesting juxtaposition in that 'Muslims may feel safer in the West, as far as the free exercise of their religion is concerned, than in so called Muslim countries' (2004: 65). The implication of this position is that the dichotomy between the two 'abodes' can no longer be sustained. The resolution to this, Ramadan suggests, rests in an exercise of critical interrogation in which European Muslims:

have no choice but to go back to the beginning and study their points of reference in order to delineate and distinguish what, in their religion, is unchangeable (thabit) from what is subject to change (mutaghayyir), and to measure, from the inside, what they have achieved and what they have lost by being in the West. (2004: 9)

To pursue this, Ramadan proposes that Islam can be appropriated in movements of reform and integration in new environments as long as the idea of the alamiyyat al-islam (the universal dimension of the teaching of Islam) is retained. Just as, he argues, the concepts of dar al-islam and dar al-harb 'constituted a human attempt, at a moment in history, to describe the world and to provide the Muslim community with a geopolitical scheme that seemed appropriate to the reality of the time' (2004: 69), in the current era what is proposed is the recognition of a third abode, dar al-dawa ('abode of prayer'). This is consistent with the ethic of Islam, he maintains, for 'Mecca was neither dar al-islam nor dar al-harb, but dar al-dawa and in the eyes of the Muslims, the whole of the Arabian Peninsula, was dar al-dawa' (2004: 72). He summarizes his position thus:

I have investigated the tools that can give an impetus, from the inside, to a movement of reform and integration into the new environments. The power and effectiveness of the 'principles of integration', which is the foundation upon which all the juridical instruments for adaptation must depend, lie in the fact that it comes with an entirely opposite perspective instead of being sensitive, obsessed by self-protection and withdrawal and attempts to integrate oneself by the 'little door', on the margin, or 'as a minority', it is on the contrary, a matter of integrating, making one's own all that people have produced that is good, just, humane - intellectually, scientifically, socially, politically, economically, culturally, and so on. (2004: 5)

Ramadan's project might then be characterized as both classicist and revisionist in that he stakes out an ethical resource in Islamic scriptures to propose a qualitatively novel solution that is calibrated to contemporary - traditionally non-Muslim majority - societies. Yet it is precisely this project of reconciliation between Islamic doctrines and European conventions that is challenged by Bassam Tibi (2008: 177), the other key exponent of 'Euro-Islam'. For if Europe is no longer perceived as dar al-Harb, and instead considered to be part of the peaceful house of Islam, 
he maintains, 'then this is not a sign of moderation, as some wrongly assume: it is the mindset of an Islamization of Europe'. He continues:

In defence of the open society and of its principles, it needs to be spoken out candidly: Europe is not dar al-Islam (or, in the cover language of some, dar al-shahada), i.e. it is not an Islamic space but a civilisation of its own, albeit an exclusive one that is open to others, including Muslims. These are, however, expected to become Europeans if they want to be part of Europe as their new home. (2004: 159)

In Tibi's view, the burden of adaptation required to cultivate a Euro-Islam must necessarily rest heavier with Muslims than amongst the institutions and conventions that constitute European societies. That is to say that a civilizational notion of Europe, one that he traces back to the age of Carolingians, must be the vessel in which Islam in Europe comes to rest. Tibi's formulation is principally driven by an anxiety over the disproportionate development of sizable Muslim communities in Europe, and the concomitant emergence of a Muslim consciousness (or in Ramadan's terms 'Muslim personality'). This leads Tibi (2008: 180) to insist that without doctrinal reforms in Islam, that is: 'without a clear abandoning of concepts such as da'wa, hijra and shari'a, as well as jihad', there can be no Europeanization of Islam. One source of Tibi's dualism centres on the relationship between religious doctrine and migration, especially with regards to the status on proselytization, meaning that 'if da'wa [prayer] and hijra [migration] combined continue to be at work; the envisioned 'Islamization of Europe' will be the result in the long run' (2008: 177). This can only be averted in Tibi's view if Muslims acknowledge that the identity of Europe is not Islamic:

It is perplexing to watch the contradictory reality of Europeans abandoning their faith while the global religionization of politics and conflict enters Europe under the conditions of Islamic immigration... The substance of the notion of Euro-Islam is aimed at the incorporation of the European values of democracy, laicité, civil society, pluralism, secular tolerance and individual human rights into Islamic thought. (2008: 153, 157)

The direction of travel here, that is to say that the focus on what needs to be revised, marks the key distinction here between Ramadan and Tibi. Hence the latter has elsewhere promoted the need for a European Leitkultur a guiding culture or leading culture - characterized by values of 'modernity: democracy, secularism, the Enlightenment, human rights and civil society' (Tibi, 1998: 154). ${ }^{2}$

\section{Eurabian nights - demographics and culture}

Tibi's concern with a civilizational identity is found in a more exclusionary manner in our second account of an emergence of a large-scale modern Muslim presence in 
Europe. Unlike the first this offers an indisputably pessimistic interpretation because it associates the Muslim presence with a number of detriments to European culture and social harmony. Sometimes sourced to the interventions of the controversial polemicist Bat Ye'or (2001, 2005), the notion of 'Eurabia' describes a numerical and cultural domination of Europe by Muslims and Islam. It is an idea that features prominently in the accounts of various best-selling authors including the late Italian intellectual Orianna Fallaci $(2001,2003)$, the German economist Thilo Sarrazin (2010), the British historian Niall Ferguson (2004), and the polemicist Melanie Phillips (2005), amongst many others. Our first exponent illustrative of this view, Mark Steyn (2006a), thus maintains that 'much of what we loosely call the Western world will not survive this century, and much of it will effectively disappear in our lifetimes, including many, if not most Western European countries'. As such, and in his America Alone: The end of the world as we know it, Steyn (2006b) insists that levels of fertility are so low that:

$[\mathrm{N}]$ ative populations are ageing and fading and being supplanted remorselessly by a young Muslim demographic. The EU will need to import so many workers from North Africa and the Middle East that it will be well on its way to majority Muslim by $2035 \ldots$ The average European Muslim has 3.5 children, whereas the average native woman has 1.5. Europe's successor population is already in place and the only question is how bloody the transfer of real estate will be. Europe is dying and America isn't...

These statistics have not gone undisputed, and indeed have been refuted by Carr (2006), Hawkins (2009), Jones (2005), Kuper (2007), and Laurence and Vaïsse (2006), amongst others, principally on the grounds that they both radically over estimate base figures and then extrapolate implausible levels of population growth. The demography panic has nonetheless achieved a degree of traction, and the same demographic fatalism is shared by Christopher Caldwell (2010) in his Reflections on the Revolution in Europe (subtitled: Can Europe Be the Same with Different People in It?). As with Steyn, Caldwell maintains that, with the exception of its Muslim members, all European societies presently fall beneath the 'total fertility rate' required for a society to remain the same size. Muslims are the exception, he insists, because in contrast to a reticent Europe, 'Muslim culture is usually full of messages laying out the practical advantages of procreation' (2010: 15). ${ }^{3}$ The outcome is that while 'in the middle of the twentieth century, there were virtually no Muslims in Western Europe...[a]t the turn of the twenty-first, there were between 15 and 17 million' (2010: 10).

The important thing to note, however, is that for Caldwell the numbers are not significant in and of themselves, but instead for the critical mass they potentially generate in incrementally expanding political challenges to European nation-state conventions. As he puts it:

If you understand how immigration, Islam, and native European culture interact in any Western European country, you can predict roughly how they will interact in any 
other - no matter what its national character, no matter whether it conquered an empire, no matter what its role in WWII, and no matter what the provenance of its Muslim immigrants. (2010: 19)

That this bold claim is open to substantial critique from both empirical and theoretical quarters is not the core issue here (see Tryandifillidou et al., 2011). We are instead concerned with Caldwell's characterization of the nature of this interaction between Muslims and European societies. This promotes the essentialist notion that Muslim identity politics is an outcome of an Islam that by definition is hostile, subversive and ultimately dominating, for in contrast to Judaism and Catholicism, in his view, 'Islam in Europe is different' because:

Since its arrival half a century ago, Islam has broken - or required adjustments to - a good many of European customs, received ideas, and state structures with which it has come into contact. Sometimes the adjustments are minor accommodations to Muslim tradition - businesses eliminating the tradition of drinks after work, women-only hours at swimming pools, or prayer rooms in office buildings, factories and department stores ... occasionally what needs adjusting is the essence of Europe. (Caldwell, 2010: 11)

This is, for Caldwell, principally a reflection of the fact that Islam in Europe rests uneasily with European traditions of secularism. Moreover, in a competition between the two - Islam and secularism - the 'arrogant view' that Europeans hold the upper hand will prove the 'biggest liability in preserving its culture' (2010: 22). This emerges as self-evident, maintains Caldwell, in the observation that 'Europeans know more about Arabic calligraphy and kente cloth because they know less about Montaigne and Goethe' (2010: 17). The implication is that 'Europe is not welcoming its newest residents but making way for them' (2010: 17). That is to say that an appreciation of Islamic cultural forms goes hand in hand with a depreciation of European cultural forms. This binary and zero sum trade-off takes a more sinister turn, however, where cultural diversity is associated with political violence because:

If the spread of Pakistani cuisine is the single greatest improvement in British public life over the past half-century, it is also worth noting that the bombs used for the failed London transport attacks of July 21, 2005, were made from a mix of hydrogen peroxide and chapatti flour. (2010: 17)

Steyn (2006: 84) too stresses the intersections between a critical mass of Muslims and broader political outcomes, but goes much further in his assertions by observing that:

Mohammed is (a) the most popular baby boy's name in much of the Western world; (b) the most common name for terrorists and murderers; (c) the name of the revered 
Prophet of the West's fastest-growing religion. It's at the intersection of these statistics - religion, demographic, terrorist - that a dark future awaits.

For Steyn there is a linear relationship between religion and jihadist violence in the current period that reflects a 'deep psychoses of jihadism's reach within Islam in general and the West's Muslim populations in particular' (2006: 81). This is neatly reflected in his question of whether the problem is not that Muslims in the West are unfamiliar with the customs of their new land, but rather that they are all too familiar with them - and explicitly reject them. The result of this is 'a mutated form of Islam' (2006: 82) that functions as a new European pan-Islamic identity. Unlike its Euro-Islam counterpart, then, this second interpretation of a Muslimsubject does not envisage space for synthesis. On the contrary, it predicts that the numbers and sheer will of Muslims will subsume the current European landmass into an Islamic enclave characterized by a 'mutated form' of Islam to be known as 'Eurabia'.

\section{Exceptional Muslim claims-making - the limits of integration}

The third interpretation of Muslim consciousness is more nuanced than the second and employs a methodology of political claims-making to report that Muslims in Europe are exceptional in not following path-dependent institutional opportunity structures of minority integration. That is to say that, taken as an aggregate, accommodating Muslims will be more difficult because Islam is more publicly confessional than other faiths, refuses to be privatized, and instead advances into the public realm of politics in collective and exceptional ways. Different exponents of this view can include Joppke (2009a, 2009b), and Koopmans et al. (2005), as well as Hansen (2006) and O'Leary (2006), amongst others. For example, in Joppke's (2009b: 108) account:

if one considers that explicit Muslim claims did not emerge in earnest before 1989, the year of the Rushdie controversy in Britain and of the first Foulard affair in France, the speed and depth of accommodating Muslims have been breathtaking, up to the point of 'laiscist' France is now providing state financed Imam education.

The explanation for this sustained and rapid claims-making may be found in the force with which 'in pious Muslims there reverberates the archaic power of religion, which is not merely subjective belief, but objective truth, which cannot leave room for choice' (Joppke, 2009a: 111). The presence of Muslims in Europe has therefore resurrected religious disputes from an earlier age. However, Joppke does not share with Caldwell the notion that there is little difference between national contexts, for while he does point to a European-wide phenomena, it is also at least one feature of what he characterizes as the 'paradox' of British integrationist policies. By this he refers to his assessment that 'while the British state has done more than other European states to accommodate the claims of Muslim minorities, recent polls 
have shown British Muslims to be more disaffected and alienated than other Muslims in Europe' (2009b: 454). This he interprets as evidence of 'the limits of [British] integration policy', and orients his stiffest critique to how allegedly the 'the neologism "Islamophobia", has functioned as a symbolic device of the British state to recognize the Muslim minority' (2009a: 111). Indeed, in a challenging and provocative account, Joppke rejects the analytical value of Islamophobia per se on the grounds that it has deflected from the 'real' causes of disadvantage, and that it fuelled a quest for recognition that stands to be disappointed. He continues:

Britain is a particularly interesting case in this respect. This is because the British case shows a puzzling disjunction between an apparently ill-adapted and dissatisfied Muslim minority and a rather accommodative state policy, which has rarely been far from what organised Muslims want the state to do. Formulated as a counterfactual, if you look for a place in Europe where you would not expect Muslim integration to pose a particular problem, you would expect this place to be Britain. (2009b: 455) ${ }^{4}$

Contrastingly, in a much more thorough and dispassionate analysis, Koopmans et al. (2005: 21) come to the same task not to prescribe a position in political theory, but instead to identify distinct features of citizenship practice, and to let them interact in order to create four possibilities. Using the two dimensions of (1) a formal basis of citizenship: civic-territorial $\mathrm{v}$ ethno-cultural, and (2) cultural obligations tied to citizenship: cultural monism and cultural pluralism, they chart the emergence of four conceptions of citizenship as follows. The first is termed an Ethnic Assimilationism (found in Germany and Switzerland); the second is an Ethnic Segregationism; the third is a type of Civic Republicanism (evidenced in France, and in a qualified manner, in the UK); and finally, Civic Pluralism (e.g. the Netherlands). Koopmans et al. (2005: 73) apply this model to the position of five countries (as bracketed above) at three moments (1980, 1990 and 2002) and find that there are two important movements between the periods of 1980 and 2002. The first is a movement towards cultural pluralism in all five countries, though to differing degrees and from quite different starting points, and the second is a movement towards civic conceptions of citizenship. In related analysis they come to the view that taken as an aggregate Muslims emerge as exceptional in their group demands for accommodation because, unlike other faiths, 'Islam cannot simply be confined to privatized religious faith, but advances into the public realm of politics where the state's authority and civic citizenship obligations reign supreme' (Statham et al., 2005: 455). To elaborate this, they stake out the difference between group demands that seek parity, and group demands that are exceptional, and discuss the issue of education to illustrate how these differ:

The example of separate schooling for Muslim girls in Britain is a parity group demand because other faith groups have state-sponsored single-gender school. 
One difference between Catholic girls' schools and Islamic ones, however, is that Islamic schools make a religious faith central to education that promotes values that are less commensurable with liberalism than modern Catholicism. Sometimes Muslim parents' arguments for faith schools make little effort to fit within the culturalism of the civic community, for example, when they express fear at the possible 'westernization' of their children. Important here is that some Muslims see Islam as being more 'true' than other faiths, and more authoritative than the state, which is problematic for liberal democracies. (2005: 431-2)

What makes Muslim claims-making exceptional in this view are the ways in which group identity and cultural demands routinely coalesce in a novel and challenging manner because, to some extent, Muslims are promoting a way of life that is antithetical to liberal democratic norms and conventions.

\section{Misrecognizing Muslim consciousness}

The sections above considered what is taken to be three salient interpretations of the emergence of Muslim consciousness in Europe. The accounts given may be open to the charge of simplification but hopefully not misrepresentation. Having summarized these positions we are now able to critically engage with each.

The first account of a Muslim subject is theologically grounded but socially iterative. While differing profoundly in important respects, both Tariq Ramadan and Bassam Tibi anchor the development of a Muslim consciousness in Europe to a doctrinal innovation in Islam. The argument presented here is that the Euro-Islam thesis assumes too linear a relationship between Islamic doctrine and Muslim identity in a way that minimizes the role of the social. ${ }^{5}$ The implication being that - no less than with any text - Islamic scriptures offer guidance that are interpreted and applied by human agents in particular social contexts. As Omid Safi (2004: 22) reminds us: 'in all cases, the dissemination of the Divine teachings is achieved through human agency. Religion is always mediated.' The point is that the meaning of a text has to be understood in terms of not just interpretations but social context.

It is suggested here that the relationship between Islam and a Muslim identity might be better conceived as instructive but not determining, something analogous to the relationship between the categorization of one's sex and one's gendered identity. ${ }^{6}$ That is to say, one may be biologically female or male in a narrow sense of the definition, but one may be a woman or man in multiple, overlapping and discontinuous ways - one's gender reflects something that emerges on a continuum that can be either (or both) internally defined or externally ascribed. This allows that in addition to the scriptural conception, we could view Muslim identity as a quasi-ethnic sociological formation, which potentially allows a range of factors other than religion (such as ethnicity, race, gender, sexuality, and agnosticism) to shape Muslim identities. 'Quasi' is used to denote something similar but not the same as because ethnic and religious boundaries continue to interact and are rarely wholly demarcated, hence the term 'ethno-religious' (see Modood, 1997a: 337). 
Compared to the purely theological variety, this sociological category might be preferred as a less exclusive and more valid way of operationalizing Muslim consciousness because it includes opportunities for self-definition (such as formally on the census or on 'ethnic' monitoring forms (see Aspinall, 2000) or informally in public and media discourse). Equally, it can facilitate the description of oneself as 'Muslim' and take the multiple (overlapping or synthesized) and subjective elements into account independently of or intertwined with objective behavioural congruence with the religious practices outlined earlier. It is maintained that this space for self-definition is a helpful means of conceptualizing the difference between externally imposed and self-ascribed identities, with both potentially becoming more prominent at some times and less at others.

This emphasizes agency in self-definition. For example, one might view Islam as a historical, civilizational edifice that has contributed to modern science and philosophy, and take pride in this, but simultaneously disassociate oneself from the religious teachings. This historical or civilizational role of Islam may be discarded in favour of the elevation and re-imagining of a particular religious doctrine, or way of being a Muslim, based upon an adherence to articles of divine and confessional faith. The point is to recognize the pragmatic possibilities that emphasis and de-emphasis confer upon the bearers of such identification, which includes the recognition that the element of choice is not a total one. By this it is meant that although one may imagine a Muslim identity in different ways, when one is born into a Muslim family one becomes a Muslim. This is not to impose an identity or a way of being onto people who may choose to passively deny or actively reject their Muslim identity. Consistent with the right of self-dissociation, this rejection of Muslim identification (or adoption of a different self-definition) should be recognized where a claim upon it is made. What is being argued is that when a Muslim identity is mobilized, it should be understood as a mode of classification according to the particular kinds of claims Muslims make for themselves, albeit in various and potentially contradictory ways.

Rather than moving to the second interpretation of the Muslim subject, this last point brings us to the third account, which characterizes Muslims in Europe as exceptional in not following path-dependent institutional opportunity structures of minority integration. It is suggested that these different positions do not offer a fair reflection of the content of mobilizations undertaken by Muslims qua Muslims. To consider this we can reflect on the issue of Muslim schools in Britain, which is raised by each author as illustrative of exceptional group demands. I have elsewhere argued that Muslim identities can inform the movement for Muslim schools in a variety of ways, and that where Muslim constituencies are granted greater participatory space in the shape of provisions for Muslim schooling, it is evident from the testimonies of Muslim educators and the content of school curricula that a reconciliation between faith requirements and citizenship commitments is a first order priority (Meer, 2009). Yet what is often overlooked in the deployment of Muslim identities in the case for Muslim schools in Britain is how the imagining of 
a Muslim identity goes hand in hand with the imagining of a British identity. This is very evident in the characterization by head teacher Abdullah Trevathan of the 'ethos' of Islamia Primary, the first Muslim school in Britain to receive state funding:

[I] fanything - this school is about creating a British Muslim culture, instead of, as I've often said in the press, conserving or saving a particular culture, say from the subcontinent or from Egypt or from Morocco or from wherever it may be. Obviously those cultures may feed into this British Muslim cultural identity, but we're not in the business of preserving... it's just not feasible and it's not sensible... it's dead: I mean I'm not saying those cultures are dead but it's a dead duck in the water as far as being here is concerned. (Trevathan, interview with author, 6 March, 2006)

Islamia Primary is not unique in trying to partner the Muslim dimension with the national, so that instead of suffocating hybridity or encouraging reification, for example, the outward projection of this internal diversity informs a pursuit of hyphenated identities. The casualty in this 'steering' of Muslim identity is the geographical-origin conception of ethnicity, what some characterise as 'de- territorialization' (Roy, 2004), and the scramble to de-emphasize the 'ethnic culture' in favour of an ecumenical Islamic identity soon gives rise to an important complaint. This includes the lack of provisions within comprehensive schooling to cater for identity articulations that are not premised upon the recognition of minority status per se, but that move outward on their own terms in an increasingly confident or assertive manner. Idris Mears, director of the Association of Muslim Schools (AMS) stresses this position:

I think a general point which is very important to get across is that state schools do not handle the meaning of Muslim identity well for the children. In actual fact, the way that general society looks at Muslims is as an immigrant minority-ethnic-racialgroup and how young people are made to look at themselves through the teaching in state schools tells them 'you are this marginal group/minority group and have therefore got to integrate with the mainstream'. So there's a process of marginalisation and that often leads to resentment. But in a Muslim school that identity is built upon being a Muslim not an ethnic minority. The impact of being Muslim is very different because the role of the Muslims in any situation is to be the middle nation to take the middle ground and be the model as witnesses of humanity. I think it gives young people a greater sense of who they are and how they can interact in society and therefore learn that Islam is not just a thing that is relevant to minority rights. Islam is relevant to economy, to foreign policy, etc., which means that we're not getting on to a stationary train but a train that is moving. (Mears, interview with the author, 1 April 2006)

This 'train' - which moves between different sites of boundary maintenance - is an articulation of Muslim consciousness. Mears expresses a 'clean' version of Muslim consciousness that is free from ethnic and racial markers and therefore does not correspond to the lived reality, but is expressed as an aspiration to be realized 
through Muslim schooling environments. It is a desire reflected in the findings of Patricia Kelly (1999: 203) who, in her ethnographic study of schooling choices made by Muslim parents with both secular and Islamic worldviews, concluded that:

as some less-religious families do opt for specifically Muslim education, we can consider this as an example of a decision to selectively emphasise this pan-ethnic (Muslim) group identity, in order to reap whatever benefits - economic, social and psychological as well as spiritual - it offers.

While this emphasizes that much of the motivation for Muslim schooling reflects the desire of Muslim parents who embrace it as a means through which to instil some sense of a Muslim heritage in all its heterogeneity, this does not make it incommensurable with liberal democratic norms and conventions. As Soper and Fetzer (2010: 13) insist: 'it is theologically naïve and historically misguided to assume Islam is any more inherently incapable of making peace with liberal democratic values than are Christian and Jewish traditions'. Statham et al. (2005), too, recognize this possibility, and illustrative of it is Mears stresses the distinction between a school premised upon an ethnic origin conception of Islam, driven by a desire for 'cultural protection zones', and an Islamically driven environment that moves outward to build upon evaluative criteria already established and in place (Mears, interview with the author, 1 April 2006). This is one strand of a broader trajectory that has seen the creation of Muslim groupings often modelled on corporatist organisations created by other, especially Jewish, faith groups e.g. the Muslim Council of Britain (MCB) and the Zentralrat der Muslime in Deutschland (ZMD) both draw upon the precedents of Jewish bodies and organizations. Meanwhile the Conseil Francais du Culte Musulman draws upon the Consitoire for Jews. What is interesting is the extent to which each has been framed within national agendas of democratic participation, and stakeholder representation and consultation, rather than as clerical or religious bodies per se.

This brings us finally to the Eurabia thesis, which predicts the numerical and cultural domination of Europe by Muslims and Islam. By now it should be apparent that the weight of evidence does not support this forecast. This is because Muslims are either innovating with Islam in Europe - both Ramadan and Tibi are evidence of this - or are pursuing well-established policy traditions within European states. Muslims are not, for example, seeking to establish the right to practise polygamy, female genital mutilation (FGM) or forced marriages. The point instead is that, as Soper and Fetzer (2010: 12) have it, 'Muslims are religiously active, but they lack the political power that well established churches have historically enjoyed, thereby threatening their capacity to win state recognition for their religious needs'. This is precisely the third of misrecognition elaborated by Laegaard' (this issue) and discussed in the introduction, and that Modood (1997b, 2007) has long sought to overcome through approaches of 'moderate secularism' and the accommodation of newer religious minorities into existing church-state relations. Recalling this reverses Caldwell's (2010) question to ask not whether 
Europe can remain the same with Muslims in it, but instead at what point, if at all, the emergence of a Muslim-consciousness will be recognized as a legitimate constituent in Europe. Put another way, at what cost will Muslim constituencies be denied a participatory space in the form of such things as provisions for Muslim schooling, discrimination legislation, and non-derogatory representation in mainstream public and media discourses? It is evident that there is a movement for some sort of synthesis by Muslims themselves. Europe boasts a rich public sphere and a series of dynamic civil societies that have historically included and incorporated other religious minorities. The question with which it is currently wrestling concerns the extent to which it can accommodate Muslims in a manner that will allow them to reconcile their faith and citizenship commitments. The alternative is to leave Muslims:

experiencing [themselves] as invisible at the same time that [they are] marked out as different. The invisibility comes about when dominant groups fail to recognize the perspective embodied in their cultural expressions as a perspective. These dominant cultural expressions often have little place for the experience of other groups, at most only mentioning or referring to them in stereotyped or marginalized ways. (Young, 1990: 60)

This kind of civic status will confer upon Muslims a sort of Du Boisian veil from behind which they must look out at dominant society, whilst those in front of it do not see them as full and legitimate co-members of their polity (Meer, 2010). That is, institutions and social practices will continue to attribute minority status to some inherent qualities, as if those qualities were the reason for, rather than the rationalization for, neither recognizing their presence nor taking their sensibilities into account. This seems especially true at moments of acute objectification, in that being 'singled out for particular interrogation in the west, Muslims have been asked to commit to patriotism, peace at home, war abroad, modernity, secularism, integration, anti-sexism, anti-homophobia, tolerance and monogamy' (Younge, 2005: 31). The point is that Muslims are not being asked to sign up to these because they are intrinsically valuable, but as 'a pre-condition for belonging in the west at all' (Younge, 2005: 31).

\section{Conclusions}

This special issue seeks, at this embryonic stage in the theorization of misrecognition, to learn from some of the intellectual weaknesses in some of the early theorizations of recognition. Taking up the opportunity presented by this special issue to consider seriously the issue of religion in general and concomitantly by drawing upon notions of recognition elaborated in our introduction, the article maintains that three prominent and influential characterizations of Muslim-consciousness misrecognize key features in the emergence of the Muslim subject amongst 
Muslims in Europe. By taking up the second key objective of this special issue, it is maintained that, unlike the intellectual tendency permeating some of the early theorizations of recognition, a context-sensitive approach can reveal that Muslims are meeting standards of reasonableness in their identity articulations, often from contexts in which they face profound social and political adversity.

\section{Acknowledgements}

I am grateful to my co-editors, Wendy Martineau and Simon Thompson, and also to Tariq Modood, for helpful comments on an earlier draft of this article.

\section{Notes}

1. He states: 'I claim the concept of Euro-Islam, first presented in Paris and published in French and German in 1992-5... . Others use the notion 'Euro-Islam' without a reference to its origins and often in a different, clearly distorted meaning. I prefer not to mention names, but nevertheless it is imperative to dissociate my reasoning on Euro-Islam from that of Tariq Ramadan, whom I consider a rival within Islam in Europe' (Tibi, 2008: 156).

2. Of course how the concept of Leitkultur has been adopted varies profoundly and may in many instances not be endorsed by TIbi himself.

3. Or as Steyn (2006b) puts it: 'Islam has youth and will, Europe has age and welfare.'

4. Unfortunately, Joppke ignores all the evidence that contradicts this view. See, amongst others, Heath and Roberts (2008) and summaries in Meer (2010).

5. I am indebted to Tariq Modood for helping me to develop this argument over the duration of my doctoral studies.

6. It should be stressed that this distinction is problematic, but is adopted as a heuristic device to develop this particular point. See Meer's (2010: 212) discussion of Butler (1990) on this point.

\section{References}

Al Sayyad N, Castells M (eds) (2002) Muslim Europe or Euroislam: Politics, Culture and Citizenship in the Age of Globalization. Lanham, MD: Lexington Books.

Aspinall P (2000) Should a question on 'Religion' be asked on the 2001 British Census? A public policy case in favour. Social Policy \& Administration 34(5): 584-600.

Braudel F (1995) A History of Civilisations. New York: Penguin.

Butler J (2006) Gender Trouble. London: Routledge.

Caldwell C (2010) Reflections of a Revolution in Europe: Can Europe Be the Same with Different People in It? St Ives: Penguin.

Carr M (2006) You are now entering Eurabia. Race \& Class 48: 1-22.

Fallaci O (2001) The Force of Reason. New York: Rizzoli International.

Fallaci O (2003) The Rage and the Pride. New York: Rizzoli International Publications.

Ferguson N (2004) The end of Europe? In: American Enterprise Institute Bradley Lecture, 1 March, Washington, DC.

Hansen R (2006) The Danish Cartoon Controversy: A defence of liberal freedom. International Migration 44(5): 7-16. 
Hawkins O (2009) Disproving the Muslim Demographics Sums. Available at: www.bbc.co.uk/ programmes/b00xw21x (accessed 25 January 2011).

Heath AF and Roberts J (2008) British Identity: its sources and possible implications for civic attitudes and behaviour. Research report for Lord Goldsmith's Citizenship Review. Available at: www.justice.gov.uk/docs/britishidentity.pdf (accessed 30 November 2011).

Holm E (1999) Forward. In: Munoz GM (ed.) Islam, Modernism, and the West. London: IB Taurus, xi-xii.

Joppke C (2009a) Veil: Mirror of Identity. Cornwall: Polity.

Joppke C (2009b) Limits of integration policy: Britain and her Muslims. Journal of Ethnic and Migration Studies 35(3): 453-472.

Jones T (2005) Short Cuts: How to concoct a conspiracy theory. London Review of Books, July 2005.

Karamustafa A (2004) Islam: A civilizational project in progress. In: Safi O (ed.) Progressive Muslims on Justice, Gender and Pluralism. Oxford: Oneworld, 111-128.

Kelly P (1999) Integration and identity in Muslim schools: Britain. United States and Montreal. Islam and Christian-Muslim Relations 10: 197-217.

Koopmans R, Statham P, Giugni M and Passy F (2005) Contested Citizenship: Immigration and Cultural Diversity in Europe. Minneapolis: University of Minnesota Press.

Kuper S (2007) The crescent and the cross. Financial Times, 11 October, 7.

Laurence J and Vaïsse J (2006) Integrating Islam Political and Religious Challenges in Contemporary France. Washington, DC: Brookings Institution Press.

Meer N (2009) Identity articulations, mobilisation and autonomy in the movement for Muslim Schools in Britain. Race, Ethnicity and Education 12(3): 379-398.

Meer N (2010) Citizenship, Identity, and the Politics of Multiculturalism: The Rise of Muslim Consciousness. Basingstoke: Palgrave.

Modood T (1997a) Difference: Cultural racism and anti-racism. In: Werbner P, Modood T (eds) Debating Cultural Hybridity: Multi-Cultural Identities and the Politics of AntiRacism. London: Zed Books, 154-172.

Modood T (1997b) (ed.) Church, State and Religious Minorities. London: Policy Studies Institute.

Modood T (2007) Multiculturalism: A Civic Idea. London: Polity.

Modood T and Meer N (2011) Framing multicultural citizenship in Europe. In: Tryandifillidou A, Modood T, Meer N (eds) European Multiculturalisms: Cultural, Religious and Ethnic Challenges. Edinburgh University Press, 33-60.

O'Leary B (2006) Liberalism, multiculturalism, Danish Cartoons: Islamist fraud and the right of the ungodly. International Migration 44(5): 22-33.

Phillips M (2005) Londonistan. London: Encounter Books.

Ramadan T (1999) To Be A European Muslim. Leicester: Islamic Foundation.

Ramadan T (2004) Western Muslims and the Future of Islam. New York: Oxford University Press.

Roy O (2004) Globalized Islam: The Search for a New Ummah. New York: Columbia University Press.

Safi O (2004) Introduction: 'The Times They Are a-changing'. In: Safi O (ed.) Progressive Muslims on Justice, Gender and Pluralism. Oxford: Oneworld, 147-162.

Sarrazin T (2010) Deutschland schafft sich ab. Berlin: Verlags. 
Soper JC and Fetzer JS (2010) The not so naked public sphere: Islam and the State in Western Europe. German Journal for Politics, Economics and Culture of the Middle East 11(2): 6-14.

Statham P, Koopmans R, Giugni M and Passy F (2005) Resilient or adaptable Islam? Ethnicities 5(4): 427-459.

Steyn M (2006a) European population will be '40 percent Muslim' by 2025. Wall Street Journal, 4 January, 17.

Steyn M (2006b) America Alone: The End of the World As We Know It. New York: Regerny Publishing.

Tibi B (1998) Europa ohne Identität, Die Krise der multikulturellen Gesellschaft. Munich: Bertelsmann.

Tibi B (2008) Political Islam, World Politics and Europe: Democratic Peace and Euro-Islam versus Global Jihad. Chippenham: Routledge.

Tryandifillidou A, Modood T, Meer N (eds) (2011) European Multiculturalism(s): Cultural, Religious and Ethnic Challenges. Edinburgh: Edinburgh University Press.

Werbner P, Modood T (eds) (1997) Debating Cultural Hybridity: Multi-Cultural Identities and the Politics of Anti-Racism. London: Zed Books.

Ye'or B (2001) Islam and Dhimmitude: Where Civilizations Collide. Madison, NJ, Fairleigh: Dickinson University Press.

Ye'or B (2005) Eurabia: the Euro-Arab axis. Madison, NJ, Fairleigh: Dickinson University Press.

Young IM (1990) Justice and the Politics of Difference. Princeton: Princeton University Press.

Younge G (2005) We can choose our identity, but sometimes it also chooses us. In: Bunting M (ed.) Islam, Race \& Being British. London: The Guardian Books, 31-32. 